\author{
УДК 349.3 \\ https://doi.org/10.34142/23121661.2020.31.11 \\ orcid.org/0000-0001-7917-9856 \\ (C) Прийменко О.С., 2020
}

О.С. Прийменко

\title{
ДО ПИТАННЯ ПРО УПОВНОВАЖЕНОГО ІЗ СОЦІАЛЬНИХ ПРАВ ГРОМАДЯН
}

\author{
O. Pryimenko
}

\section{TO THE QUESTION ABOUT THE OMBUDSMAN FOR SOCIAL RIGHTS OF CITIZENS}

\begin{abstract}
Анотація. Метою статті є аналіз доцільності введення спеціалізованої уповноваженої особи (омбудсмена) для вдосконалення системи державного контролю за дотриманням соціальних прав (насамперед права на соціальний захист). Відзначається, що питання введення уповноваженого із соціальних прав громадян не отримало належної уваги з боку вчених. Велика кількість звернень громадян до різних державних органів щодо порушень соціальних прав $є$ важливим аргументом для врегулювання статусу уповноваженого із соціальних прав громадян на законодавчому рівні. У статті запропоновано перелік основних завдань уповноваженого із соціальних прав громадян 3 урахуванням досвіду роботи Уповноваженого Верховної Ради України та різних спеціалізованих омбудсменів.

Ключові слова: соціальні права, омбудсмен, соціальний захист, спеціалізований уповноважений, звернення громадян.
\end{abstract}

Аннотация. Целью статьи является анализ целесообразности введения специализированного уполномоченного лица (омбудсмена) для усовершенствования системы государственного контроля за соблюдением социальных прав (прежде всего, права на социальную защиту). Отмечается, что вопрос введения уполномоченного по социальным правам граждан не получил должного внимания со стороны ученых. Большое количество обращений граждан в различные государственные органы относительно нарушений социальных прав является важным аргументом для урегулирования статуса уполномоченного по социальным правам граждан на законодательном уровне. В статье предложен перечень основных задач уполномоченного по социальным правам граждан с учетом опыта работы Уполномоченного Верховной Рады Украины по правам человека и различных специализированных омбудсменов.

Ключевые слова: социальные права, омбудсмен, социальная защита, специализированный уполномоченный, обращения граждан.

Abstract. The purpose of the article is to analyze the feasibility of introducing a specialized authorized person (ombudsman) to improve the system of state control over observance of social rights (primarily, the right to social protection). It is noted that the issue of introducing the commissioner for social rights of citizens has not received due attention from scientists. A large number of citizens' appeals to various state bodies regarding violations of social rights is an important argument for regulating the status of the commissioner for social rights of citizens at the 
legislative level. The article presents a list of the main tasks of the commissioner for social rights of citizens, taking into account the experience of the Verkhovna Rada of Ukraine Commissioner for Human Rights and various specialized ombudsmen.

Key words: social rights, ombudsman, social protection, specialized commissioner, citizens' appeals.

Соціальний вектор розвитку України має підкріплюватися реальним упровадженням i гарантуванням прав людини, що передбачає існування розвиненого державного механізму. Крім уже звичних органів, які опікуються питаннями соціального забезпечення (зокрема Міністерства соціальної політики України), постає потреба пошуку нових, більш ефективних моделей взаємовідносин людини й держави, дієвих засобів захисту прав і свобод людини.

Розуміючи нагальність реформування наявної системи контролю за дотриманням соціальних прав загалом і права на соціальний захист зокрема науковцями сформовано чимало пропозицій. Питання шляхів дотримання соціальних прав розглядалося О. Абрамовою, Б. Бєгічевою, Н. Болотіною, О. Мачульською, С. Монастирським, О. Москаленко, Ю. Орловським, П. Пилипенком, С. Прилипко, С. Синчук, М. Шумило, О. Ярошенком та багатьма іншими як українськими, так і закордонними дослідниками.

Мета статті - проаналізувати сучасну систему державного контролю за дотриманням соціальних прав (насамперед права на соціальний захист) в аспекті доцільності запровадження спеціальної уповноваженої особи (омбудсмена) для вдосконалення роботи зазначеної системи.

Беззаперечно, у цьому контексті важлива роль надається парламентському контролю за дотриманням конституційних прав і свобод людини та громадянина, який здійснює Уповноважений Верховної Ради України з прав людини (далі - Уповноважений).

У ст. 3 Закону України «Про Уповноваженого Верховної Ради України 3 прав людини» визначається, що метою парламентського контролю є захист прав і свобод людини та громадянина, проголошених Конституцією України, законами України та міжнародними договорами України; дотримання та повага до прав і свобод людини й громадянина; запобігання порушенням прав i свобод людини та громадянина або сприяння їхньому поновленню [1]. Із цього випливає можливість Уповноваженого захищати конституційне право осіб на соціальний захист, що містить право на забезпечення їх у разі повної, часткової або тимчасової втрати працездатності, утрати годувальника, безробіття 3 незалежних від них обставин, а також у старості та в інших випадках, передбачених законом [2].

Як зазначають О. Рудік та Л. Лазарєва, у зв'язку з втручанням держави в різні сфери життя, надання громадянам більшої кількості послуг збільшується залежність осіб від держави. Одним із механізмів захисту прав, крім суду, стає омбудсмен [3]. Сьогодні загальновизнана доцільність і обгрунтованість існування такого інституту, як Уповноважений, зокрема для реалізації соціальних прав громадян. 
За даними Щорічної доповіді Уповноваженого про стан дотримання та захисту прав і свобод людини й громадянина в Україні, 2018 р. надійшло понад 2,5 тис. повідомлень про порушення прав людини у сфері соціального захисту, що становить більше ніж 37 \% від загальної кількості звернень про порушення соціальних і економічних прав. Значна частина 3 понад 2,5 тис. повідомлень стосувалася питань пенсійного забезпечення, пільгового проїзду, порушення прав громадян, постраждалих унаслідок Чорнобильської катастрофи, погашення заборгованості за судовими рішеннями щодо здійснення пенсійних та інших соціальних виплат, проблем у призначенні субсидій [4]. Указана статистика засвідчує наявні складнощі в гарантуванні права на соціальний захист i актуалізує пошук нових підходів до вдосконалення системи державного контролю за дотриманням досліджуваного права.

Отже, можна констатувати, що сьогодні постає проблема спеціалізованого захисту окремих видів прав. Як указують дослідники, це обумовлено потребою «розширення охоплення контрольної діяльності, специфікою державного та адміністративно-територіального устрою» [3] та додаткового захисту в державі «окремих груп населення або ж окремих прав, реалізація яких для людей і держави має особливе значення» [5]. Крім того, аргументом на користь спеціалізованого підходу слугує кращий рівень розгляду чітко обмеженого кола звернень від громадян.

Варто також нагадати, що в Україні вже запроваджені спеціалізовані уповноважені (омбудсмени) для окремих категорій осіб (за сферою) чи для вирішення окремих питань: Уповноважений Президента України з прав дитини (Указ Президента України від 11 серпня 2011 р. № 811 в редакції Указу Президента України від 01 вересня 2015 р.); Уповноважений Президента України з прав людей з інвалідністю (Указ Президента України від 01 грудня 2014 р. № 902); Уповноважений із захисту державної мови (Закон України від 25 квітня 2019 р.); освітній омбудсмен (постанова Кабінету Міністрів України від 06 червня 2018 р. № 491); Рада бізнес-омбудсмена (постанова Кабінету Міністрів України від 26 листопада 2014 р. № 691); Урядовий уповноважений $з$ прав осіб з інвалідністю (постанова Кабінету Міністрів України від 24 липня 2019 p. № 665).

Водночас відсутній спеціальний уповноважений, наприклад, 3 прав пенсіонерів або малозабезпечених громадян, хоча потреба, як мінімум обговорення цього питання, існує. На жаль, незважаючи на статистику звернень до різних органів, зокрема центральних органів виконавчої влади, соціальні права залишаються майже поза увагою.

Наведемо деякі дані щодо питань, які порушували громадяни у своїх зверненнях до Міністерства соціальної політики України у 2018 р.: пенсійне забезпечення - 11823 (34,0 \% від загальної кількості звернень); субсидії - 7242 (20,8\%); пільги та компенсації - 1917 (5,5\%); усиновлення та соціальний захист прав дитини - 1709 (4,9\%); оплата праці - 1645 (4,7\%), соціальний 
захист осіб з інвалідністю - 1473 (4,2 \%); соціальний захист сімей 3 дітьми $1092(3,1 \%)$ тощо.

Отже, кількість звернень до Міністерства соціальної політики України, що стосуються соціального захисту прав дитини й соціального захисту сімей із дітьми є суттєво меншою, ніж з питань, пов'язаних із пенсійним забезпеченням. До Уповноваженого Верховної Ради 3 прав людини $з$ приводу порушень прав дітей 2018 р. звернулося 934 особи, а 3 приводу соціальних прав - 4173, що вчетверо більше.

Зазначені вище дані не можна тлумачити так, що сам факт створення посади уповноваженого (у даному випадку Уповноваженого Президента України $з$ прав дитини) може автоматично вплинути на зниження кількості звернень. Як свідчать наведені нижче дані про відсоток звернень щодо соціального захисту прав дитини і соціального захисту сімей із дітьми, їхня кількість, навпаки, з кожним роком збільшується. Так, 2015 р. це було 4,6 \%, 2016 р. 5,6 \%, 2017 р. - 5,9\%, 2018 р. - $8 \%$ [6]. Кількість звернень щодо пенсійного забезпечення коливалася від 23,1 \% до 37,2 \% за ці роки. За даними щорічних доповідей Уповноваженого, різниця між кількістю звернень щодо порушень соціальних прав і прав дітей становить близько $10 \%$ [7].

Отже, спостерігається ситуація, коли, по-перше, різниця в кількості звернень суттєва, по-друге, існує окрема посада Уповноваженого Президента 3 прав дитини (нами не заперечується доцільність їі створення), проте питання про уповноваженого із соціальних прав громадян не розглядається і навіть не ставиться на порядок денний під час обговорень захисту соціальних прав. На мою думку, така ситуація не є виправданою і не відповідає процесу розбудови інституту уповноваженого (омбудсмена).

Як зазначає О.В. Марцеляк, омбудсмен - це «призначений вищими органами державної влади контрольно-наглядовий, правозахисний, незалежний, політично нейтральний, одноособовий чи колегіальний орган державної влади (посадова особа), уповноважений конституцією чи законом за власною ініціативою або зверненням громадян контролювати діяльність органів і посадових осіб (насамперед виконавчої гілки влади) з точки зору дотримання ними прав і свобод людини та громадянина, який, зазвичай, діє неформально на власний розсуд та рекомендує коригувальні дії, спрямовані на належне забезпечення цих прав і свобод» [8]. 3 цього визначення випливає те, що омбудсмен $є$ уповноваженою особою на здійснення контролюючих функцій для гарантування прав людини, як правило, з боку виконавчої влади.

Зрозуміло, що у сфері соціальних прав існують проблеми, їх чимало. Переважно вони пов'язані 3 діяльністю виконавчої гілки влади. Тому є всі підстави пропонувати для покращення роботи та ефективності наявних гарантій виконання законодавства про соціальний захист населення створення окремого уповноваженого (омбудсмена) із соціальних прав громадян.

Діяльність цієї інституції, на нашу думку, має бути спрямована на здійснення державного контролю за дотриманням насамперед права на 
соціальний захист малозабезпечених осіб та тих, хто перебуває у складних життєвих обставинах.

Принципово важливим є повноваження, кількість залучених працівників, а найголовніше - створення умов для ефективної роботи. Держава повинна звернути увагу на стан дотримання соціальних прав в Україні, дієвість їхнього захисту.

Дискусійним питанням є вибір органу, який призначатиме зазначеного уповноваженого. Варто обговорювати два провідні варіанти: Президент України або Кабінет Міністрів України, тобто мова йде про створення Уповноваженого Президента України із соціальних прав або Урядового уповноваженого iз соціальних прав. На наш погляд, буде це уповноважена особа Президента України чи Уряду, зараз не таке першочергове питання порівняно із загальною спрямованістю на створення цього інституту як самостійної одиниці.

Спираючись на досвід різних спеціалізованих уповноважених, пропонується покласти такі основні завдання на уповноваженого із соціальних прав:

- сприяння реалізації державної політики в соціальній сфері, спрямованій на забезпечення права на соціальний захист, гарантований Конституцією України;

- запобігання в межах компетенції порушень соціальних прав людини;

- здійснення державного контролю за дотриманням законодавства в соціальній сфері, міжнародних соціальних стандартів та правил;

- вживання заходів для забезпечення належних умов для рівного доступу до соціальних виплат;

- моніторинг за виконанням Україною міжнародних зобов'язань щодо дотримання в Україні соціальних прав людини;

- участь у підготовці проектів нормативно-правових актів Міністерства соціальної політики України у сфері соціального захисту;

- співпраця та взаємодія з Міністерством соціальної політики України та іншими центральними органами виконавчої влади, органами місцевого самоврядування, правоохоронними органами, міжнародними організаціями, підприємствами, установами, неурядовими громадськими організаціями 3 питань, що належать до його компетенції;

- сприяння імплементації міжнародних соціальних стандартів;

- сприяння у виконанні Україною міжнародних зобов'язань щодо права на соціальний захист.

3 урахуванням цих завдань покладені повноваження мають здійснюватися уповноваженим як безпосередньо, так і через представників у регіонах. Наявність представництва в обласних центрах, на нашу думку, відіграє дуже важливу роль. На порушення соціальних прав треба реагувати швидко, тому наведена пропозиція $є$ доцільною. До того ж, зменшення навантаження на центральний апарат варто визнати перевагою в такій системі відносин. 
Отже, варто наголосити на наявній необхідності проведення змін 3 питань гарантування дотримання соціальних прав людини, насамперед права на соціальний захист для малозабезпечених осіб та тих, хто перебуває в складних життєвих обставинах. Значна кількість звернень громадян до Міністерства соціальної політики України, Уповноваженого Верховної Ради 3 прав людини підтверджує актуальність створення окремої інституції уповноваженого із соціальних прав. Діяльність цього органу сприятиме реалізації та захисту порушених соціальних прав громадян. У переліку завдань окреме чільне місце має надаватися наближенню законодавства щодо соціальних прав до стандартів Свропейського Союзу та інших розвинених країн.

На законодавчому рівні варто врегулювати статус уповноваженого із соціальних прав громадян. Подальших наукових досліджень потребує питання обгрунтування доцільності існування спеціалізованих уповноважених 3 прав людини, удосконалення законодавства із захисту соціальних прав.

Окремої детальної розробки потребує процедурна складова діяльності уповноваженого, формулювання статусу його регіональних представників. Ураховуючи вищевикладене, пропонується найближчим часом запровадити інститут спеціалізованого уповноваженого із соціальних прав громадян, попередньо розробивши необхідну нормативну базу його діяльності та представників у регіонах.

\section{Література}

1. Про Уповноваженого Верховної Ради України з прав людини: Верховна Рада України; Закон України від 23 грудня 1997 р. № 776/97-BP. URL: http://zakon.rada.gov.ua/ laws/show/776/97-bp; 2. Конституція України від 28 червня 1996 р. № 254к/96-BP. URL: https://zakon.rada.gov.ua/laws/show/254к/96-вp; 3. Рудік О., Лазарєва Л. Інститут спеціалізованого і місцевого омбудсмена як механізм захисту прав людини: зарубіжний досвід. Державне управління та місцеве самоврядування. Збірник наукових праць. 2011. Вип. 3(10). URL: http://www.dridu.dp.ua/vidavnictvo/2011/2011_03(10)/11romlzd.pdf; 4. Щорічна доповідь Уповноваженого про стан додержання та захисту прав і свобод людини і громадянина в Україні. URL: http://www.ombudsman.gov.ua/files/Dopovidi/Report-2019.pdf; 5. Алмаші I.M. Освітній омбудсмен як інституційна гарантія у сфері забезпечення прав людини на освіту. Науковий вісник Ужгородського національного університету. Серія «Право». 2019. Вип. 58. Т. 1. С. 61-66; 6. Довідка про роботу із зверненнями громадян, які надійшли до Міністерства соціальної політики України у 2015-2018 pp. URL: https://www.msp.gov.ua/news/8131.html; https://www.msp.gov.ua/news/12366.html; https://www.msp.gov.ua/news/14749.html;

https://www.msp.gov.ua/news/16593.html; 7. Щорічні доповіді Уповноваженого про стан додержання та захисту прав і свобод людини і громадянина в Україні у 2015-2018 рр. URL: http://www.ombudsman.gov.ua.; 8. Марцеляк О.В. Конституційно-правовий статус інституту омбудсмана: світовий досвід та українська модель: автореф. дис... д-ра юрид. наук. Одеса, 2004. 36 c. 